\title{
THE RELIABILITY OF THE TRADITIONAL SCIENCE OF HADITTH: A Critical Reconsideration
}

\section{Kamaruddin Amin}

Lecturer at UIN Alauddin Makassar

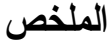

من بين الإثكاليّات في دراسة الحديث هي وجود الحقبقة بأنّ تدوين الحديث حلث في

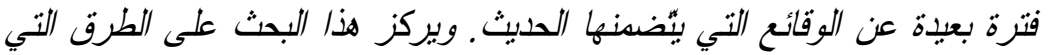

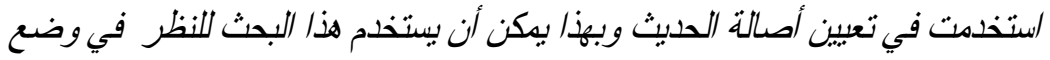
مكانة الحدبث في الدراسات الإسلاميّة.

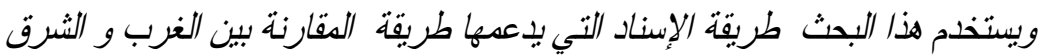

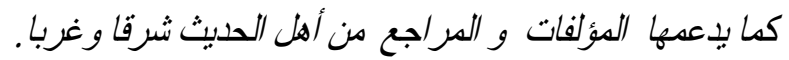

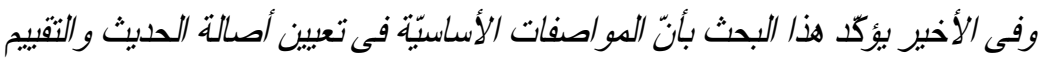

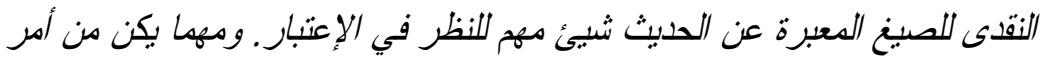

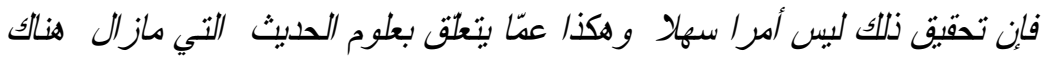

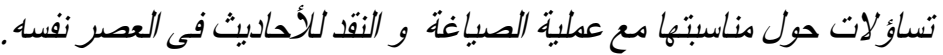

\section{Abstrak}

Satu hal yang begitu krusial dalam studi hadis adalah adanya fakta bahwa kodifikasi hadis dilakukan pada waktu yang cukup jaub dari peristiwa-peristiwa yang dinarasikannya. Untuk itu, tulisan ini memfokuskan pada metode-metode yang digunakan untuk menenetukan keotentikan hadis. Dengan demikian, riset ini dapat menjadi pertimbangan untuk menempatkan hadis dalam studi Islam. Riset ini menggunakan pendekatan isnad yang didukung dengan metode komparatif, pendekatan Barat dan Timur. Metode ini diperkuat dengan karya-karya dan literaturliteratur para abli hadis Barat dan Timur. Tulisan ini akbirnya menegaskan bahwa dasar-dasar kritreria dalam menentukan keotentikan 
hadis dan evaluasi kritis terhadap bentuk-bentuk dalam mentransmisikan hadis merupakan hal yang fundamental untuk dipertimbangkan. Walaupun demikian, bentuk-bentuk itu tidak mudah diinvestigasi karena mereka dapat digunakan secara bergantian. Begitu juga dengan ulumul hadis yang masib perlu dipertanyakan tentang keselarasannya dengan praktek pentransmisian dan kritik terbadap hadis pada masanya.

Keywords: ḥadith, reability, transmission, shädh, illa.

\section{A. Introduction}

The majority of Muslims believe that badiths are the carrier and the vehicle of the sunna of the Prophet. ${ }^{1}$ Indeed, they are indispensable guide to an understanding of the divine will. ${ }^{2}$ As one of the sources of Islamic authority, which is only second in importance after the Qur'an, the immense corpus of hadith continues to exercise a decisive influence. It has become a source of law and religious inspiration. Islamic scholarship has devoted tremendous efforts to gathering and classifying the hadiths and distinguishing the authentic from the false ones ${ }^{3}$. While the motives of Muslim scholars to study hadith have been decisively motivated by the central role played by hadiths as the source of their law and theological doctrine, the interests of modern Western scholars in the study of hadith literatures have essentially been historical. Similarly, when they study Islamic law, for example, they tend to approach it as a mode of thought rather than as a body of rights, obligations and rules of procedure. In other words, they are not lawyers

${ }^{1}$ H. A. R. Gibb, Mohammedanism, Oxford, 1949, pp. 74-5; Ahmad Hasan, ”The Sunna, its Early Concept and Development", in Islamic Studies, (vol. 7, 1968), p. 48.

${ }^{2}$ Muḥammad b. Idrīis al-Shāfīị, Kitāb al-Risāla, ed. Aḥmad Muhammad Shākir, Cairo, 1358/1940, p. 84;. Muḥammad Muḥammad Abū Zahw, al-Hadith wa'Muḅaddithü, Cairo, 1957/1378, p. 11. There is a discussion about whether the sunna should be classified as ilhäm rather than waby. See William A. Graham, Divine Word and Prophetic Word in Early Islam: A Reconsideration of the Sources, with Special References to the Divine Saying or Hadith Qudsi, The Hague, 1977, p. 35.

${ }^{3}$ The major collections are: Muhammad b. 'Abd Allāh al-Bukhārì (d. 256 A.H.),

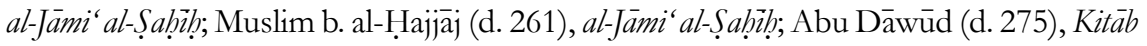
al-Sunan; al-Tirmidhì (d. 279), Sunan, al-Nasā̄i (d.303), Kitāb al-Sunan; Ibn Māja (d.273), Kitāb al-Sunan; al-Dārimi (d. 225), Kitāb al-Sunan. 
but students of culture ${ }^{4}$.

One of the problems of Islamic hadith literatures is that their texts were codified much later than the events they narrate. This fact leads to the issue of the missing link between badith literatures and the events they describe. Historical questions must be asked: To what extent does our hadith literature reflect the actual events it narrates? Does hadith literature provide really transmitted hadiths or are these badiths nothing but reflections of interests, which evolved in early Islam? To put it in more technical terms: Do the matns of hadiths reflect the actual words of the Prophet or Companions, or do they constitute a verbalization of what, much later, came to be realized as being Prophetic sunna? Do the isnäds attached in hadith literature to guarantee the authenticity of the matns represent the genuine lines of transmission, or do they constitute forgeries intended to legitimize statements first circulated at a later time? Does the occurrence of a certain hadith in the canonical collections prove the historicity of its ascription to the Prophet, which would make further research superfluous?

By virtue of the fact that the answer of the above questions needs or deserves more spaces than we have here, it is not possible to deal exhaustively with any of the above question. However, in the brief discussion, an effort has been made to highlight a small part of the questions, i.e., how reliable the methods for determining the authenticity of hadith are.

\section{B. Western Scholarship of Hadith}

Since the 19th century, questions about the authenticity, originality, authorship, provenance and the correctness of hadith have appeared, and they have become of central importance to the study of Islam, especially to those concerned with Islamic law. Gustav Weil, for example, suggested that a European critic is required to reject at least half of al-Bukhārís șạiḥ ${ }^{5}$. The first serious challenges to the authenticity of Muslim hadith literature by Western scholars began with

${ }^{4}$ R. Stephen Humphreys, Islamic History: A Framework for Inquiry, Princeton, 1991, p. 209.

${ }^{5}$ Gustav Weil, Geschichte der Chalifen, vol. 2. p. 291. 
Alois Sprenger, ${ }^{6}$ who expressed his skepticism about the reliability of hadith as a historical source. This attitude was followed by William Muir, who also maintained a critical attitude toward the authenticity of hadith ${ }^{7}$. European scholarship of hadith culminated in the work of Ignaz Goldziher, whose work was unquestionably the most important critique of hadith in the nineteenth-century. Goldziher was the first scholar to subject the hadith to a systematic historical and critical study ${ }^{8}$. Instead of considering hadith as reliable sources for the rise of Islam, he regard it as invaluable source for the beliefs, conflicts and concerns of the generations of Muslims who came after and put the hadith into circulation. As he himself put it:

"Das Hadith wird uns nicht als Dokument für die Kindheitsgeschichte des Islam, sondern als Abdruck der in der Gemeinde hervortretenden Bestrebungen aus der Zeit seiner reiferen Entwicklungsstadien dienen; es bietet uns ein unsch tz̧bares Material von Zeugnissen für Entwicklungsgang, den der Islam w hrendjener Zeiten durchmacht, in welchen er auseinander widerstrebenden $\mathrm{Kr}$ ften, aus $m$ cbtigen Gegens tzen sich zu systematischer Abrundung herausforme"

Goldziher's skepticism was adopted by Leone Caetani and Henri Lammens who were of the opinion that almost all the traditions about the Prophet's life were apocryphal ${ }^{10}$. Other scholars who refused hadith as authentic materials for the historical reconstruction of the time of

${ }^{6}$ Alois Sprenger, "On the Origin and Progress of Writing Down Historical facts among the Musulmans," Journal and Proceeding of the Asiatic Society of Bengal 25 (1856), pp. 303-329, 375-381; "Die Sunna" in Alois Sprenger, Das Leben und die Lehre des Mohammad, lxxvii-civ. Berlin, 1861-1865.

${ }^{7}$ William Muir, The Life of Mabomet and the History of Islam to the Era of Hegira, 4 vols. London, 1861; reprint. Osnabruck, 1988. First serialised in Calcutta Review 19 (January-June, 1853).

${ }^{8}$ Ignaz Goldziher, Muhammedanische Studien, 2 vols. Leiden, 1889-1890. Trans. S. M. Stern as Muslim Studies, 2 vols. London, 1967.

${ }^{9}$ Ignaz, Goldziher, Muhammedanische Studien, II, p. 5.

${ }^{10}$ L. Caetani, Annali dell'Islam, vol. 1, Milan, 1905, pp. 28-58, 121-43, 192-215 and passim; H. Lammens, "Qoran et tradition. Comment fut composée la vie de Mahomet", in: Recherches de Science Religieuse, 1 (1910), pp. 27-51, quoted by Harald Motzki, The Biography of Muhammad: the Issue of the Sources, Brill, 2000, p. xii.

${ }^{11} \mathrm{~J}$. Wansbrough, The Sectarian Milieu, Content and Composition of Islamic Salvation History, Oxford, 1978. 
the Prophet and the first Islamic century are John Wansbrough ${ }^{11}$ and Patricia Crone and Michael Cook ${ }^{12}$. Although in Western scholarship Goldziher's Mubammedanische Studien was considered to be the first milestone among Western efforts to depict the history of hadith, he met with criticism from Muslim scholars ${ }^{13}$. In western scholarship, Goldziher's book, published in 1890, was not followed by similar studies and remained unrevised in any significant way until Joseph Schacht's Origins of Mubammadan Jurisprudence appeared in 1950. Schacht dealt especially with legal tradition and their development. ${ }^{14}$ His thesis that isnäds have a tendency to grow backwards' and his "common link theory" have influenced the Western scholars who came after him. Like Goldziher, he assumed that few if any hadith originated with the Prophet. He believed, however, that it was possible by careful study to arrive at a rough estimate of when a particular hadith was put into circulation. Schacht's approach has been adopted by J. van Ess ${ }^{15}$ and has been revived in a large scale by G. H. A Juynboll, even though he differs from Schacht in several significant points ${ }^{16}$. This is reflected in Juynboll's method of dating a ḩadith by invariably posing three questions: Where a certain hadith originated, at what time a certain hadith originated and who may be held responsible for bringing a certain hadith into circulation ${ }^{17}$. By posing the three questions, in his view, the problems of chronology, provenance and authorship of a certain hadith 1977.

${ }^{12}$ P. Crone and M. Cook, Hagarism. The Making of the Islamic World, Cambridge,

${ }^{13}$ Mustafa-. M. Azami, Studies in Early Hadith Literature with a Critical Edition of Some Early Texts, Beirut 1968. This book has been translated into Arabic with the title Diräsat fi'l-Hadith al-Nabawi wal-Tärikh Tadwinih, Beirut, 1968; Muștafāa al-Sibā̄í, al-Sunna wa-Makēnatubä fil-Tashri' al-Islämi, Cairo, 1961, pp. 365-420.

${ }^{14}$ Joseph Schacht, The Origins of Muhammadan Jurisprudence, Oxford, 1950.

${ }^{15}$ Joseph van Ess, Zwischen Hadith und Theologie: Studien zum Entstehen pr destinatianischer berlieferung, Berlin/New York, 1975.

${ }^{16}$ G. H. A. Juynboll, Muslim Tradition. Studies in Chronology, Provenance and Authorship of Early Hadith, Cambridge, 1983; Studies on the Origins and Uses of Islamic Hadith, 1996.

${ }^{17}$ G. H. A. Juynboll, "Some isnād analytical method illustrated on the basis of several women - demeaning sayings from ḥadith literature" in: al-Qantara: Revista de estudos arabes, 10 (1989), pp. 343-383; repr. in Studies on the Origins...; Muslim Tradition, .... 
can be assessed. Juynboll's method of dating a certain ḥadith by analysing the isna d of a single tradition has become a powerful tool of research. Both Schacht and Juynboll are of the opinion that the common link is the fabricator of hadith ${ }^{18}$. Schacht's and Juynboll's method of dating a hadith by analysing the isnād has been subjected to criticism ${ }^{19}$. Perhaps the most significant challenges to their conclusions may be found in Harald Motzki's works ${ }^{20}$. Unlike Schacht and Juynboll, Motzki is inclined to regard the common links not as the fabricators of hadiths as Schacht and Juynboll do, but rather as the first systematic collectors of traditions who transmitted the hadiths in regular classes of students out of which an institutionalized system of learning developed ${ }^{21}$. Opposition to Schacht's and Goldziher's assumptions about the badiths may also be found in the works of M. Sibā ${ }^{-} 1$, N. Abbott, M. M. Azami and F. Sezgin. They argue for an early and continuous practice of writing down ḩadith in Islam. In their opinion the Companions of the Prophet kept written records of hadith, and most of these a ha ädith were transmitted in written form until the time they were compiled in the canonical collections $^{22}$. Motzki and Schoeler have also pointed out, what Schacht and Juynboll denied that some hadiths can be dated to

${ }^{18}$ Schacht, Origins, pp. 171-172. Juynboll, "Some-isnäd analytical methods"

${ }^{19}$ Michael Cook, Early Muslim Dogma. A Source Critical Study, Cambridge 1981, pp. 109-111 and "Eschatology and Dating of Traditions", in: Princeton Papers in Near Eastern Studies I (1992), pp. 23-47.

${ }^{20}$ Harald Motzki, "Quo vadis, Hadith Forschung? Eine kritische Untersuchung von G. H. A Juynboll: "Nafi', the mawla of Ibn 'Umar, and his Position in Muslim hadith Literature" in: Der Islam 73 (1996) 40-80 und 193-229; 'The Musannaf of 'Abd alRazzāq al-San'āni as a Source of Authentic Abăäith of the First Century A.H: in:Journal of Near Eastern Studies 50/1 (1991), pp. 1-21 ; Die Anf nge der Islamischen Jurisprudence. Ihre Entwicklung in Mekeka bis zur Mitte des 2./8 Jahrbunderts, Stuttgart 1991; 'Der Fiqh des Zuhri: die Quellenproblematik' in Der Islam 68 (1991), p. 1-44.

${ }^{21}$ Motzki, "Quo vadis", p. 45; "Der Prophet und die Schuldner. Eine hadith Untersuchung auf dem Prüfstand" in: Der Islam 77 (2000), p. 9. "Methoden Zur Datierung von islamischen berlieferungen", Nijmegen 2001, pp. 10-12.

${ }^{22}$ Nabia, Abbott, Studies in Arabic Literary Papyri II: Qur'anic Commentary and Tradition, The University of Chicago Press, 1976; M. M. Azami, Studies in Early Hadith Literature: With a Critical Edition of Some Early Texts. 1968. 3rd ed. Indianapolis 1992; Fuat Sezgin, Geschichte des arabischen Schrifttums, Band I: Qur'änwissenschaften, Hadith, Geschichte, Figh, Dogmatik, Mystik bis ca. 430 H., Leiden, 1967. 
the first century. However, whether or not they can be ascribed to the Prophet, has not been proved $^{23}$.

\section{The Reliability of 'Ulūm al-Hadith}

The fact that there were unreliable hadiths beside reliable ones was not only and first realized by Western scholars. Muslim scholars were already aware of it at the end of the first century A.H. or even earlier. It can be assumed that the corpus of hadith, which developed in the first century, ${ }^{24}$ was a mixture of both reliable and unreliable hadith. As a response to this, early Muslims created a system of evaluating the hadith so that the true and the false might be distinguished ${ }^{25}$. The classical science of hadith criticism consisted of three branches. The first dealt with the riwayat, i.e. investigated the chains of transmission to establish the continuity of their constituent links. The continuity of the isnäds was evaluated for missing or unknown mubaddiths or for stopping at a Companion or Successor and not going back to the Prophet. The second branch was concerned with asmä' al-rijal, i.e. provided biographical information on the ruwat (transmitters) of hadith as a basis for judgments of their reliability. The attention focused on the date and place of birth, familial connections, teachers, students, journeys, moral behavior, religious beliefs, literary output, and date of death. This allowed the determination not only of their reliability but also the contemporaneity and geographical proximity of the transmitters. This helped to determine whether or not the transmitters could have

\footnotetext{
${ }^{23}$ For traditions dated in the first century cf. Harald Motzki, "The Prophet and the Cat: On Dating Mālik's Muwatta' and Legal Traditions" in JS AI 22 (1998) p. 18-83; Die Anf nge; "Der Fiqh des Zuhri, p. 1-44; "The Muṣannaf, p. 1-21; "The Prophet und die Schuldner"; Gregor Schoelar, Charakter und Authentie der Muslimischen berlieferung über das Leben Mubammad, Berlin, 1996.

24 See note 23.

${ }^{25}$ The most famous of the early ones being al-Risla by al-Shfi' + (204), alMuhaddith al-Fàsil bayna'-Rāwi wa'l-Wāir by al-Rāmahurmuzì (d. 360), Ma'rifa 'Ulūm al-

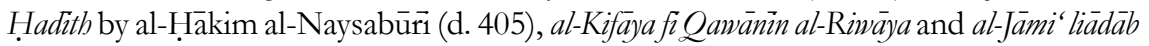

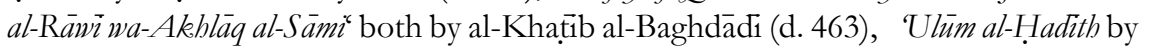
Ibn al-Ṣalạ̄ (d. 643/1245).
} 
come in contact with each other ${ }^{26}$. The third branch of Muslim badith criticism considered the content of a hadith i.e. whether or not it was in accordance with the Qur'an and with hadiths that were considered reliable.

The methods of the muhaddithin, however, have been subjected to criticism. The objection to their reliability in ascertaining the authenticity of hadiith came even from Muslim and non-Muslim scholars. Ibn Khaldūn (d. 808/1406) was of the opinion that when traditionists scrutinized religious accounts, they based their judgment only on the bearer of the information. If they were trustworthy, then the information they transmitted was automatically considered to be authentic. Ibn Khaldūn, therefore, believes that the scrutiny of badith that has been done by traditionists is restricted to the scrutiny of isnād alone $^{27}$. The Egyptian writer, Ahmad Amin (d. 1373/1954) seems to agree with Ibn Khaldūn. He states that the traditionists when scrutinizing the hadith, paid more attention to the isnäd than to the mat $^{28}$. Abu Rayya argues that the mubaddithin were concerned only with the continuity of the transmission and the character of the transmitters, and they completely ignored the essential content of traditions and they failed to look at the historical evidence ${ }^{29}$. These views of Ibn Khaldūn, Aḥmad Amin and Abü Rayya have been refuted by Muṣtafā al-Sibā̄ị, Muhammad Abū Shuhba and Nūr al-Dìn 'Itr. They are of the opinion that the 'ulamá of hadith did not neglect the matn at all. This can be seen in the criteria laid down by the traditionists in which it is stated that the hadith can be regarded to be authentic only if its sanad and matn are free from shädhdh (strange or isolated) and 'illa

${ }^{26}$ Biographical dictionaries contain an entry for each transmitter. One of the earlier examples of biographical dictionaries is al-Tabaqāt al-Kubrā of Muhammad ibn Sa'd (d. 230/844), which has some 4,300 entries.

${ }^{27}$ Ibn Khaldūn, Muqaddima, p. 37.

${ }^{28}$ Aḥmad Amin, Fajr al-Islàm, p. 217-218; Duhāa al-Islām, vol 2, pp. 130-134. Similar to the view of Abu Rayya is that of 'Abd al-Mun'im al-Bāhi. He maintains that the scrutiny of the matn is only considered by the traditionists. This view quoted by Nür al-Din 'Itr in al-Madkhal ilà 'Ulüm al-Hadith, p. 14.

${ }^{29}$ Maḥmūd Abū Rayya, Aḍwā 'alà'-Sunna al-Muhammadiyya, p. 4-6; Ahmad Khan, Maqālāt, I, 27-28 quoted by Daniel W. Brown, Rethinking Tradition in Modern Islamic Thought, Cambridge 1996 p. 97 
(sickness i.e. any consideration which impairs the sihha or 'soundness' of any hadith). ${ }^{30}$

This controversy reminds us of the fact that the issue of the reliability and historicity of the hadith is far from being resolved. Although al-Bukhärr's (d. 256) and Muslim's (d. 261) Saḩ̣̣̂̉s are regarded as the most reliable works of hadith, ${ }^{31}$ nowhere have they directly mentioned the criteria they applied to test the authenticity of hadith. Later scholars, however, have tried to infer al-Bukhārin's and Muslim's requirements for authentic hadith. ${ }^{32}$ It was inferred that the requirements by both of them are the same to a large extent. But to some extent they are different. The conditions they have in common are as follows. (1) The chain of transmission from the first transmitter to the last one must be uninterrupted (an yakūn al-ḥadith muttasil al-isnād). (2) The transmitters must be well known for their thiqa, i.e., 'adl (righteous conduct) and dabt (high literary accuracy) from the first tier to the last one (bi-naql al-thiqa 'an thiqa min awwalih ilà muntabāhu). (3) The transmitted ḥadith must be free from illa (defect) and shudhüdh (irregularness) (sātiman min al-shudhüdh wa'-'illa). Ibn al-Șalāh said that if these condition are met by a particular hadith, then it would be considered authentic by the traditionists (abl al-ḥadith) without any disagreement. ${ }^{33}$

The essential difference of al-Bukhārì's and Muslim's requirements for authentic hadith lies in the continuity of the chain of transmission, i.e., the necessity for establishing a meeting between two

${ }^{30}$ Nūr al-Din 'Itr, al-Madkhal ilà 'Ulüm al-Hadith, pp. 15-17; Introduction to Ibn al-Ṣalāh in 'Ulūm al-Hadith li ibn al-Salāh, pp. 13-14; al-Sibā̄i, al-Sunna wa-Makānatubā, pp. 296-303.

${ }^{31}$ Ibn Kathir, al-Bä ìth al-Hathith, Cairo n.d., p. 25; al-Qastalānì, Irshäd al-Säri liSharḥ Saḥiḥ al-Bukhärï, Bagdad, 1304, pp. 19-20.

${ }^{32}$ Al-Qastalānī, Irshād, p. 19-20; Maḥmūd al-Ṭaḥhān, Taysir Mustalaḥ al-Hadith, Beirut, 1399/1979, p. 45; M. Syuhudi Ismail, Kaedah Kesabihan Sanad Hadis: Telaah Kritis dan Tinjauan dengan Pendekatan Ilmu Sejarah, Jakarta, 1988, p. 107; Muhammad Zubayr Siddiqi, Hadith Literature: Its Origin, Development and Special Features, Cambridge, 1993, p. 56; Ibrāhìm b. al-Ṣiddiq, Maqālät wa-Muḅădarāt fi l-Hadith al-Sharif wa- 'Ulümih, Beirut; Dār al-Bashā'ir al-Islāmiyya, 2002/1423, pp. 7-33.

${ }^{33}$ Quoted by al-Nawawi, Saḥị̣ Muslim bi-Sharḥ al-Nawawi, Beirut, n.d., vol. 1, p.15. 
transmitters. Al-Bukhārỉ held that a tradition cannot be accepted unless it is known that the transmitter encountered the man whose authority he quotes, even if they met only once (la budda min thubüt al-liqä). The proof of being contemporaries (mu'așara) alone is considered insufficient by al-Bukhāri. Muslim, however, did not require the proof of meeting between them. The proof of being contemporaries is, in his view, enough. ${ }^{34}$ In other words, if a non-mudallis transmitter relates a hadith with a word indicating direct contact $\left(\operatorname{sam}_{\bar{a}}\right)$, such as akbbaranā, anba'anā, sami'tu, etc, both al-Bukhāri and Muslim alike accept the hadith. But in the case that a non-mudallis transmitter relates a badith from a transmitter with a word which might imply both $s a m \bar{a}^{-6}$ (direct contact) and indirect transmission, such as 'an fulàn, etc, then al-Bukhāri and Muslim hold different opinions. While al-Bukhārì requires that the transmitter encounter the informant from whom he transmitted the badith ('an'ana) even though only once, Muslim is content with their being contemporaries and only the probability of encounter. As to the transmission of a mudallis with the term 'an both al-Bukhārì and Muslim reject it if the mudallis' hearing of the hadith in question is not clear to them. In such a case, both al-Bukhāri and Muslim require the proof of hearing (thubüt al-samā') for each ḥadith transmitted by a mudallis. Accordingly, if they provide an isnäd of 'an'anat mudallis they give an additional isnād in order to remove the possibility of tadlis. ${ }^{35}$ Yet the fact that there are, as will be shown, a large number of hadiths, found in the Sabỉhs of al-Bukhārī and Muslim which were related by allegedly mudallis transmitters, and using the word 'an, one may wonder how consistent al-Bukhāri and Muslim were in the application of their alleged method. Based on the investigation of the 194 hadiths transmitted by Abū al-Zubayr from Jābir found in Muslim's Sahịh and 43 hadiths transmitted by al-Hasan al-Bașri from different companions found in the Saḥ̣̂̆s of al-Bukhāri and Muslim, I argue that for both alBukhāri and Muslim, the terminology of transmission used by the first

${ }^{34}$ Badr al-Din Abi Muhammad Maḥmūd Ibn Aḥmad al-'Aynī, 'Umdat al-Qāri Sharh Sahīh al-Bukhäri, Beirut, n.d., vol. 1, p. 5; Ibn Kathir, al-Bä ith al-Hathith Sharh

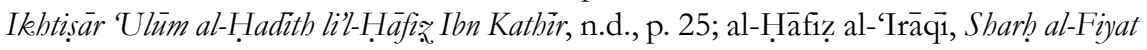
al-Iräqi, p. 40; al-Qastalāni, Irshäd, p. 20.

${ }^{35}$ Ibrāhim b. al-Ṣaddiq, Maqālat wa-Mụ̣ạdarāt fi al-Hadith al-Sharif, pp. 17-8. 
century scholars was not a decisive criterion to determine the reliability of a particular hadith.

Later traditionists such as Ibn al-Ṣalāh (d. 643/1245), al-Nawawi (d. 676/1277), Ibn Kathir (d. 774) Ibn Hajar al-'Asqalāni (d. 852/1449), Jalāl al-Din al-Suyựị (d. 911/1505) and others have given definitions of hadith sahỉ (reliable hadith). Their definitions, although differently worded, essentially represent what al-Bukhārì and Muslim have allegedly adopted. They can be summarized as follows: (1) Continuity of transmission (2) all transmitters in the isnäd must be 'adl (3) all transmitters must be däbit (4) isnād and the matn must be free from shudhüdh (5) isnād and matn must be free from 'illa. ${ }^{36}$ These requirements will be critically elaborated in the following section.

\section{The Continuity of Transmission}

It has been stated above that the continuity of transmission is one of the principal requirements for a hadith to be regarded as reliable. The continuity of the chain of transmission means that all transmitters in the chain from the first tier (compiler) to the last one (Companion) have transmitted the hadith in a reliable manner in the light of tahammul wa-adä' al-hadith, i.e., each transmitter in the chain transmitted the given badith directly from the preceding transmitter, and all transmitters in the chain are thiqa, i.e., 'adl and däbit.

To know whether there is continuity of transmission, the biography of each transmitter required careful scrutiny. This scrutiny focused on the transmitter's date and place of birth and his date and place of death. His behavior and religious belief had also to be evaluated very carefully. This information allegedly helped the critical scholars not only in their attempt to establish the thiqa (reliability) of transmitters, but also to ascertain the probability or improbability of transmitters having come in contact with their informants. With regard to the relation of respective transmitters, the examination of words

${ }^{36}$ al-Shahrazūrî, 'Ulüm al-Hadith, ed. Nūr al-Din 'Itr, Madinah, n.d., p. 10; Jalāl al-Din al-Suyūtị, Tadrì al-Rāwi fi Sharh Taqrỉb al-Nawawi, ed 'Abd al-Wahhāb 'Abd alLaṭif, Madinah, 1972/1392, p. 63; Aḥmad Muhammad Shākir, Sharḥ Alfiyyat al-Suyūtì fi 'Tlm al-Hadith, Beirut, n.d., p. 3; Al-Hāfị̣ al-'Irāài, Sharḥ Alfiyyat al-Irāqi al-Musammā bi'l-Tabsira wa'l-Tadhkira, vol. 1, p. 12; Ibn Kathir, al-Bä'ith al-Hathith, p. 21. 
connecting the transmitter with their preceding authority were extremely important, because the words used by the transmitters are thought to imply how the given hadith was transmitted. The words often used were sami'tu, ḥaddathani, ḥaddathanā, akbbarani akbbaranā, 'an, anna and so on. These words allegedly implied different meanings, which reflected the various possible relationships between the transmitter and his preceding informant.

In order to be able to grasp any information on transmitters, sources containing biographical information had to be available. One may wonder whether such sources existed when the hadiths were critically collected. Such early books as al-Tlal of AГi al-Madini (d. 234/ 848), Kitāb al-'Ilal wa-Ma'rifat al-Rijäl of Ahmad b. Hanbal (d. 241) Kitāb al-Ṭabaqāt al-Kabir by Ibn Sa'd ${ }^{37}$ (d. 230/844), Tarikh al-Kabir of al-Bukhārì (d. 256) may answer this question. Moreover, the appearance of some early critical ḥadith experts like Shu'ba b. al-Hajjajj ${ }^{38}$ (d. 160/777), Yahyā b. Sa íd al-Qattānn ${ }^{39}$ (d. 198/813), Yahyā Ibn Ma in (d. 233/847), 'A I Ibn al-Madini (d. 234/848, al-Husayn b. 'A Karābisisi (d. 245/859), al-Jūzjānìi (d. 256/870), al-Bukhārìi (d. 256/870, Abū Ḥātim (d. 277/890), Ya'qūb b. Sufyān al-Fasawì (d. 277/890) ${ }^{40}$, may well suggest that the beginning of hadith criticism were made before the hadiths were collected into corpora claiming to contain only reliable traditions. Another question, which has to be answered, is whether the information on the transmitters available in the biographical dictionaries enabled collectors like al-Bukhārì and Muslim to form a clear judgment about the transmitters' characters and qualities? As some studies have shown 41 the information of the biographical dictionaries enables us to grasp some further information on the transmitters, and reference to it is indispensable for historical reconstruction. Some of their information, however, need to be reconstructed and must be approached critically.

${ }^{37}$ Although this book does not specifically deal with al-jarb wa'-ta'dill, it is considered to be a reliable source of rijäl al-ḥadith, see Mạ̣mūd al-Ṭaḥhān, Usūul alTabkrij wa-Diräsat al-Asānid, p. 153.

${ }^{38}$ Ibn Hajar, Tahdhib, iv, p. 345; Cf. Juynboll, Muslim Tradition, p. 20.

${ }^{39}$ Ibn Hajar, Lisān, I. p. 5, al-Dhahabi, al-Käshif, I. p. 25. Cf. Juynboll, Muslim Tradition, p. 20.

${ }^{40}$ For some other names see Juynboll, Muslim Tradition, Appendix IV. 
In addition to the continuity of transmission, the reliability (thiqa) of a transmitter is an absolute requirement for an uninterrupted hadith. To be reliable, one must first be 'ádil, i.e. of righteous conduct. In other words, the transmitter's character must be acceptable from the Islamic point of view. The 'adil transmitter must not have committed a grave sin nor have been prone to commit minor sins. ${ }^{42}$ The scholars of hadith have further specified the requirements for those to be called 'ádil. Ibn Hajar al-'Asqalāni mentions five conditions ${ }^{43}$ i.e. fear of God (taqwa), morally well behaved (murü'a), freedom from guilt for major sins, not performing bid'a, not being fásiq. Ibn al-Ṣalāh has mentioned five conditions as well: Muslim, adult (bäligh), sane ('áqì), behaving morally (murü'a), not being fasiq ${ }^{44}$ Thus, 'adala is a gift that always keeps someone behaving piously and invariably prevents him from having a bad character. ${ }^{45}$ Subsequently, it leads someone be able to tell the truth. One may wonder, however, whether this quality of ' $a d l$ actually prevents someone from making mistakes by the grace of God, because mistakes are not necessarily made consciously.

The transmitter must also be däbit, i.e. having high literary accuracy as transmitter. To determine the accuracy of the transmitters, the muhaddithün used at least two methods: consulting the scholars' judgments about a transmitter and comparing his transmission with other transmissions. These methods are reflected in the statements ascribed to early scholars. Ayyūb al-Sakhtiyāni, a late successor (68$131)$ is reported to have said for example: "if you wish to know the mistakes of your teacher, then you ought to study with others as well."

${ }^{41}$ See Kamaruddin Amin, The Reliability of Hadith Transmission. A Reexamination of Hadith Critical Methods (Ph. D Dissertation), Bonn 2005; Harald Motzki, Die Anfaenge der islamischen Jurisprudence. Stuttgart 1991.

${ }^{42}$ Ibn al-Athïr, Jämi' al-Usūul fi Ahäădith al-Rasūl, n.d., vol. 1, p. 74.

${ }^{43}$ Ibn Hajar, Nuzhat al-Naz̧ar. p. 13. For other scholars who have proposed requirements for being called 'adl see, al-Hākim al-Naysabūrì, Ma'rifa 'Ulüm al-Hadith, p. 53; Ibn al-Salāh, 'Ulüm al-ḥadith, p. 94; al-Nawawi, al-Taqrỉb, p. 12; , Nūr al-Din 'Itr, Manhaj al-naqd fi 'ulum al-ḥadith, p. 79-80.

${ }^{44}$ Ibn al-Salah, 'Ulüm al-hadith, p. 4. See also, Syuhudi Ismail, Kaedah Kesabihan Sanad Hadis, p. 115.

${ }^{45}$ Muḥammad Qāsim al-'Umarì, Dirāsat fi manhaj al-naqd 'inda l-muhaddithin, Yordan 2000, p. 250. 
"To reach an authentic statement concerning authenticity of tradition, one needs to compare the words of scholars with each other" ${ }^{\prime \prime 6}$. This method of comparing the report of a transmitter with those of others can be found in the basic handbook of classical Islamic badith criticism, in Ibn al-Salāh's Muqaddima. He says:

"Whether or not the narrator is accurate can be ascertained by comparing his material with the narration of sound narrators (thiqait) who are well-known for their control of their material and their thoroughness. If (1) we find his narration to be in accordance with their narration, even if only in content or (2) we find that his narrations are usually in accordance with their narrations and that he rarely differs from them, then we will know that he is in control of his material and is reliable $(d \bar{a} b i t)$. But if we find that he often differs from the sound narrators we will know that he is not reliable and we will not use his badith as basis for argumentation. God knows best". ${ }^{47}$

By this method of comparison, the mubaddithin were allegedly not easily misled by seemingly sound isnāds. Al-Hākim (d. 405/1014) in his Ma'rifa 'Ulüm al-Hadith quoted an isnäd whose men are all trustworthy, but pointed out that the hadith attached contained inaccuracies. He quoted the isnād Mălik from al-Zuhri from 'Urwa from 'A'isha, and said it was false as far as Mālik's tradition is concerned, although it was handed down by imäms and trustworthy persons. He argued that what is sound is known not only by its transmission, but also by understanding, learning by heart and hearing a great deal. He also argues that other hadiths with seemingly sound isnäds can be accepted as free from defect only after discussion with people who have knowledge of the subject ${ }^{48}$. In the following an example of badith criticism is given in which a comparison is made between the hadiths of different students of one scholar:

Ibn Main (d. 233) went to 'Affān, a pupil of the great scholar Hammād b. Salama, to read the books of Hammād to him. 'Affān asked him whether or not he had read those books to any other students of

${ }^{46}$ Azami, Studies in Hadith Methodology and Literature, p. 52

${ }^{47}$ In 'Abd Rahìm b. Husayn al-'Irāqi's (d. 805) al-Taqyìd wa-sharḥ muqaddimat Ibn al-Salāh, al-Maktaba al-salafiyya, 1996, p. 166

${ }^{48}$ Cf. James Robson, The Isnäd, p. 25 
Hammād. Upon which Ibn Ma'in replied: 'I have read those books to seventeen students of Hammād before coming to you'. 'Affann said: 'By Allah I am not going to read these books to you'. Ibn Ma'in answered that by spending a few dirhām he would go to Bașra and read them there to the students of Hammād. He went to Bașra to Mūsā b. Ismā̄inl, another pupil of Hammād. Mūsā asked him 'Have you not read these books to anybody else? He said I have read them completely to seventeen students of Hammād and you are the eighteenth one'. Müsā asked him what he was going to do with all those readings. Ibn Ma in replied: Hammād b. Salamah made mistakes and his students added some more mistakes to his. So I want to distinguish between the mistakes of Hammād and those of his students. If I find all the students of Hammād making the same mistake, then the source of mistake is Hammād. If I find the majority of Hammād's students say something, and some of them say something else, then this mistake was committed by that particular student of Hammād. In this way I make a distinction between the mistakes of Hammād and those of his students. ${ }^{49}$ It is evident that by his method of comparison Ibn Ma in could indeed discover the mistakes of, and to assess the accuracy of, both Hammād and his students. ${ }^{50}$

On the other hand, in practice the dabt of a transmitter has been mostly determined on the basis of the judgments of scholars. This procedure faces the problem that the judgments of scholars on a

${ }^{49}$ Azami, Studies in Hadith Methodology, pp. 52-53.

${ }^{50}$ A similarly method was applied by Iftikhar Zaman. He has succeeded in showing the possibilities of reaching judgments regarding the transmitters of a certain text by scrutinising the variations of the text which are transmitted through different transmitters. To corroborate his theory he has analysed the hadith regarding the Prophet's visiting $\mathrm{Sa}^{\mathrm{d}} \mathrm{d} \mathrm{b}$. Abi Waqqās while the latter was ill. After analyzing the variant versions of the hadith, he argued (1) "The significance of the mass of the textual material known as hadith is best understood and explained in the light of such a science of rijal (2) Evaluating the factual contents of hadith with the use of such a science will lead to results which are much more reliable than any of the methods modern scholars have proposed for the study of hadith". See Iftikhar Zaman "The science of Rijal as a method in the Study of Hadith" in Journal of Islamic Studies 5:1 (1994) p. 1. The same method has been used by H. Motzki in his works "Der Fiqh des Zuhri", "Qua vadis", "The Prophet and the Cat", 'The Murder of Ibn Abi 1-Huqayq". 
transmitter often differ. Some scholars, in judging the transmitters, are mutashaddid (having a stern viewpoint), some are mutasăbil (lenient) and some others are mutawassit (in the middle). These different attitudes of scholars led to different judgments. The diversity of scholars' knowledge on a particular narrator led also to the variety of judgments. According to some a transmitter may be thiqa, but according to others he may not.

Furthermore, we may wonder how early the method of comparing transmitters' narrations to determine their accuracy was used and whether it was applied on a large scale. Are the hadith collections the result of applying this method? Was the statement ascribed to Ibn al-Mubārak (d. 181) ${ }^{51}$, an early Muslim scholar of badith, stating "To reach an authentic statement concerning the authenticity of tradition, one needs to compare the words of scholars with other's" always adopted in early Islam? Was it merely the opinion of a single scholar or a norm generally hold? Was the method, which was adopted by Ibn Main, generally practiced in early Islam? These questions lead us to a problematic and controversial issue of research. It seems difficult to imagine that the hadith literature, i.e., the classical collections, are the result of such a systematical procedure. Had scholars of hadith applied the system consistently from the beginning, many inauthentic hadiths had not found their way into the hadith collections. Accordingly, it seems justified to ask whether the classical rules of "ulum al-hadith were applied generally and consistently before this "science" was established.

Azami is of the opinion that the method of Ibn Main was practiced from the beginning of Islam. To corroborate his claim, Azami puts forward some examples. Abū Bakr, 'Umar b. Khațāà, Abū Hurayrah and " 'isha, according to Azami, practiced the method ${ }^{52}$. It should be stated, however, that what Abū Bakr and other Companions did to compare the transmission is different from that of Ibn Main. Ibn Main tried to reconstruct the original text of a mubaddith, which had been transmitted through the latter's students. He did it

51 Khațib, Jàmi', 5a, quoted by Azami, Studies in Hadith Methodology, p. 52.

52 Azami, Studies in Hadith Methodology and Literature, pp. 53-55. 
systematically by collating and comparing as far as possible the transmission of students, whereas Abu Bakr and other Companions tried to find out the truth of an assertion in an ad hoc manner. It was not a systematic procedure of hadith criticism in the way that Ibn $\mathrm{Ma}^{5}$ in did. This might have also been done by everyone else in the same situation. This procedure to find out the truth by asking witnesses was used by the judge. So, Azmi's claim that both methods are the same kind needs to be reconsidered. It is probably justified to assume that the practice of comparing one transmission with others was inspired very early on, but Ibn Ma'in's method as a systematic procedure of hadith criticism was probably only applied in the second century of Islam. The badith collections do not seem to allow us to be sure, that this method was strictly and generally practiced in early Islam. Had the method been applied consistently, there would have been no forgery and contradictory transmission in hadith literature. Whether or not the compilers of the allegedly authentic hadith collections have applied Ibn Ma'in's method can only be tested by a critical investigation of the collections.

With regard to the scrutiny of the narrators' characters and qualities a number of sources have become available ${ }^{53}$. These books, however, were written later than the persons they describe. Again, we encounter an epistemological problem. To what extent can we lay credence on the information available in the biographical dictionaries (kutub al-rijall)? This question has been answered in different ways. The majority of Muslim scholars regard the books as historical sources, while most Western scholars reject them or are, at best, skeptical about them. Those who reject those sources as not providing historical facts distrust the capacity of the authors of the biographical reports and their collections to judge the character of the hadith transmitters. These biographical sources are, in their opinion, subject to weaknesses and

${ }^{53}$ Al-Ṭabaqāt al-kubrā by Ibn Sa‘d, (d. 230), Tarikh al-kabir by al-Bukhārì (d. 256), Al-jarḥ wa-l-ta'dill by Ibn Abi Hātim (d. 327), Usd al-ghābat fi ma'rifat al-sahāāa by Ibn alAthir (d. 630), Tahdhỉb al-kamäl by al-Mizzi (d. 742), Tadhkirat al-huffäzand Siyar a läm al-nubalā' by al-Dhahabi (d. 748), Al-Ișäba fi tamyiz al-sahāaba, Tahdhīb al-tahdhỉb by Ibn Hajar al-'Asqalānì (d. 852) Al-istí áb fi má rifat al-aṣ̣ăb by Ibn 'Abd al-Barr (d. ?), to name only the most important. 
corruption. How is it possible to ascertain the reliability of hadiths on the basis of transmitters whose reliability is uncertain? ${ }^{54}$ They even argue that although the mubaddithin did their best to get all the relevant information, they could not be sure of what they did, for it is not easy to judge people who have been dead for a long time. ${ }^{55}$ Therefore ' $i l m$ al-rijal, in their opinion, is only an approximate science. ${ }^{56}$

\section{Free from shudhūdh}

A shädhdh (irregular) hadith according to al-Shäfi ${ }^{\top} 1$ is a badith which is transmitted by a trustworthy transmitter, but contradicts the narration of the people who are regarded as more reliable than him $^{57}$. A ḅadith transmitted by only one reliable transmitter and not confirmed by any other transmitters cannot be seen as shädhdh. ${ }^{58}$ In other words, the absolute singleness of transmission (fard mutlaq) ${ }^{59}$ does not affect the reliability of a hadith as long as it has been transmitted by a reliable transmitter. In the light of this definition, the well-known hadith, "actions are (judged) according to their intentions", is not considered shädhdh, despite the fact that it was related by only one transmitter at each stage: Yahyā b. Sãd from Muhammad b. Ibrāhim al-Taymi from 'Alqama from 'Umar, all of whom are trustworthy authorities. A badith is considered to be $s h \bar{a} d h d h$ when (1) all of its transmitters are reliable (thiqa), (2) it has more than one transmitter, but (3) its matn or its sanad contradicts other transmissions, which are considered more reliable. ${ }^{60}$

${ }^{54}$ Sidqi, "Kalimāt fi al-naskh," in al-Manār 11 (1908): 693.

${ }^{55}$ Ahmad Khan, Maqālat, I, 27-28, quoted by Daniel W. Brown, Retbinking Tradition in Modern Islamic Thought, p. 97

${ }^{56}$ Cf. Wael B Hallaq, "'’The Authenticity of Prophetic hadith: a Pseudo Problem" in Studia Islamica 89 (1999), p. 75-90.

${ }^{57}$ If a narration that goes against another authentic hadith is reported by a weak narrator, it is known as munkar (denounced).

${ }^{58} \mathrm{Al}-\mathrm{Sha}$ fíi's's statement is transmitted by Ibn al-Salāh in his 'Ulüm al-ḥadith, p. 68 and al-Hākim in his Ma'rifat 'ulum al-ḥadith, p. 148; Ibn Kathir, al-Bä'ith al-ḥathith, p. 56; al-Suyūtî, Tadrib al-rāwi, I, p, 232.

${ }^{59}$ If a particular hadith is solely transmitted by ablMakeka, or only by ablMadina, or exclusively by abl Basra or Küfa or by other centre and not transmitted by any other centres, this kind of transmission is called fard nisbi. See al-Suyūṭi., I, pp. 248-251.

${ }^{60}$ Syuhudi Ismail, Kaedab Kesabihan Hadis, p. 123. 
Al-Hākim is stricter in this regard. A shädhdh hadith in his view is that which is reported by only one reliable transmitter, without being confirmed by any other reliable transmitters ${ }^{61}$. In other words, the absolute singleness of transmitter (fard mutlaq), no matter how reliable he is, causes a certain hadith to have the status of shädhdh. Ibn alSalāh, al-Nawawi and other later scholars are in agreement with alShāfir ${ }^{6}{ }^{62}$

If al-Hākim's view is adopted, many hadiths that have been considered by the majority of traditionists to be saḩih might turn out to be not sahihi, ${ }^{63}$ because, as Juynboll has rightly pointed out, the general feature of hadith literature is that hadith was generally transmitted by single persons in the generations of the Companions and Successors. It was only after these generations that hadith was massively transmitted. This is not to say, however, that nowhere in hadith collections can we find a badith that was transmitted on a large scale in the generation of Companion and Successors. Indeed, it is not difficult to find such a hadith. Yet the fact that hadith was allegedly transmitted by a large number of people belonging to the generation of the Companions does not necessarily mean that its ascriptions to the Prophet is trustworthy. It is necessary to investigate whether the ascription of transmitters from the last transmitter (collector) to the earliest one (Companion) are historical. I do not argue against the possibility that later generations mistakenly ascribed hadiths to certain Companions or purposely invented them. I only argue against the total rejection of the possibility that there are hadiths which go back to Companions. In other words, the claim of each transmitter to have received a particular hadith from his informant must be investigated to establish whether or not it is true. Yet, like many scholars, I argue that if there is conclusive evidence that a particular hadith goes back to two or more Companions and the latter claim to have received the hadith from the Prophet, then their ascription must be regarded as trustworthy.

${ }^{61}$ Al-Hākim, Ma'rifat 'Ulūm al-ḥadith, p. 119; al-Suyūṭi, Tadrỉb al-rāñ̄, p. 233.

${ }^{62}$ Ibn al-Salāh, 'Ulüm al-ḥadith, pp. 68-70; al-Suyūṭi, Tadrỉb al-rāwi, I, pp. 232-238; Subḥi al-Sāliḥ, 'Ulüm al-ḥadith wa-muṣtalaḥubu, Dimashq 1973, p. 196-203.

${ }^{63}$ Syuhudi Ismail, Kaedah Kesabihan Sanad Hadis, p. 124. 
If the view of al-Shäfí is preferred, we encounter the question of how much we can trust the transmission line of a single transmitter. This question is closely related to the issue of how we can assess, with some degrees of certainty, the reliability of a transmitter, which has been explained above. In Western scholarship this kind of transmission is known as "single strand", ${ }^{64}$ and its historical reliability is debated. Juynboll rejected the historicity of such a transmission. In his view, it is historically improbable to imagine that in early Islam a certain transmitter gave his sahiffas to just one pupil to be copied, and the latter passed them on similarly to just one pupil to be copied and the last mentioned passed them on to another single pupil to be copied again in the same fashion, because in early Islam, according to Juynboll, sabifas are described as going from hand to hand, even if there was no formal master-pupil relationship between the original compiler and later transmitters. Motzki interprets the phenomenon of single strands differently. A single strand, in his view, does not necessarily mean that it was the only way, through which the hadith was transmitted. Single strand exclusively means that when spreading hadiths, common links ${ }^{65}$ or collectors mentioned only one way of transmission. ${ }^{66}$ This difference of interpretation will be dealt with in more detail in the next chapter. ${ }^{67}$

The traditionists admitted the difficulties of detecting $s h \bar{a} d h d h$ h.adiths. This is because the transmitters of an irregular ḅadith are considered reliable by scholars of hadith, and the transmission seems to be uninterrupted. It can only be discovered after research in depth by, for example, comparing many isnäds and matns of related hadiths. Only those who are well-trained and well-versed in the scrutinizing of b.adiths can detect shädhdh ḥadiths.

${ }^{64}$ This term is coined by Juynboll.

${ }^{65}$ The meaning of this term and how it works will be elaborated in the next chapter.

${ }^{66}$ Harald Motzki, "Quo vadis, Hadith Forschung?”, pp. 45-46.

${ }^{67}$ See the following discussion on the concept of ,common link“. 


\section{Free from Tlla.}

A ma'lil hadith (defective hadith) is one that appears to be sound at first sight, but when studied more carefully a disqualifying factor becomes obvious. Such factors can be: (1) declaring a ḥadith musnad ${ }^{68}$ when it is in fact mursal,,$^{69}$ or marfü ${ }^{-70}$ when it is in fact manqü $f^{71}$; (2) that a transmitter narrated a badith from a shaykh (teacher) when in fact he did not meet the latter; or attributing a hadith to a certain Companion when in fact it comes from another Companion. ${ }^{72}$ This defect can happen not only to the isnäd but also to the matn. ${ }^{73}$ Only those who are well versed, having excellent memories and are expert of isnàds and matns can distinguish defective hadiths from reliable ones. 'Abd alRahimān b. Mahdì (d. 194) even said that in order to be able to reveal a ma'lül badith, one needs intuition (ilhām). ${ }^{74}$ Ibn al-Madinì (d. 234) and al-Khațib al-Baghdāđi (d. 463) said that a defect in the isnād can only be revealed if all isnäds of a particular hadith are collated and analyzed $^{75}$. Being a very complicated branch of mustalah al-ḥadith, only a few scholars such as Ibn al-Madinì (d. 234), Ibn Abì Hātim al-Rāzi (d. 327), al-Khallāl (d. 311) and Dāruqutnī (d. 385) have compiled books about it. Based on the above explanation, it may be justified to say that it is not safe to judge transmitters as reliable or unreliable before checking what they transmit. The judgment, whether or not the transmitter of a particular hadith is reliable, which is solely based on scholars' judgment without checking it, leads potentially certain sound

${ }^{68}$ A badith which a traditionist reports from his teacher from whom he is known to have heard ( adiths) at a time of life suitable for learning, and similarly in turn for each shaykh (teacher), until the isnād reaches a well-known Companion, who in turn reports from the Prophet, see al-Hākim, Ma 'ifat 'ulüm al-ḥadith, Cairo 1937, p. 17.

${ }_{69}$ "Hurried", i.e., when a Successor says "The Prophet said..."

${ }^{70}$ A narration from the Prophet

${ }^{71}$ A narration from a Companion only.

${ }^{72}$ Ibn al-Salāḥ, 'Ulüm al-ḥadith, pp. 81-82; al-Suyūṭi Tadrỉb al-rāwì, p. 252; Ibn Kathir, al-Bä'ith al-ḩathith, p. 65.

${ }^{73}$ For examples of defective hadiths see Ibn al-Salāh, 'ulüm al-ḥadith, p. 83; alHākim, Ma'rifat 'ulūm al-ḥadith, pp. 112-118; Ibn Kathir, al-Bā'ith al-ḥathith, pp. 67-71.

${ }^{74}$ Al-Hākim, Ma'rifat 'ulüm al-ḥadith, p. 113; al-Suyūṭi, Tadrib al-rāwi, I, p. 252.

${ }^{75}$ Ibn al-Salāh, 'Ulüm al-ḥadith, p. 82; al-Suyūtị, Tadrìb al-rāwi, I, p. 253; Ibn Kathir, al-Bä'ith al-ḥathith, pp. 65. 
hadiths to be considered as defective hadiths when scrutinized more thoroughly or vice versa.

A hadith that does not meet the above mentioned requirements cannot be regarded as reliable hadith, and cannot have religious authority. ${ }^{76}$

\section{Some Points to be Reconsidered}

If we have a look on the criteria for determining the authenticity of hadith coined by Muslim scholars, an intriguing question appears: On what grounds are the criteria based? Did they develop speculatively or were they based on a critical evaluation of hadith transmission itself? According to the "science of hadith" there were eight forms of transmitting hadith: (1) Samā', i.e., the student attends the lectures of a traditionist, which may take the form of a simple narration of the traditions, or be accompanied by their dictation, either from memory or from a book. The terminology to be used in this kind of transmission was sami'tu, ḩaddathani, akbbaranā, or anba'anā. (2) Qira'́a, i.e., the student reads to the traditionists the traditions which have been narrated or compiled by the latter. The terminology to be used were akbbarani or qara'tu 'alā. (3) Ijāza. That is, to obtain the permission of a scholar to narrate to others the traditions compiled by him. The terminology to be used in this case was akbbarani or ajazani (4) Munawwala. That is,

${ }^{76}$ The final verdict on a hadith is whether it is sahĭh (reliable), hasan (good), Da iff (weak) or maudū' (fabricated, forged). Ibn al-Salāh classifies Hasan hadiths in two catagories: (1) One with an isnād containing a reporter who is mastür ("screened", i.e., no prominent person reported from him) but is not totally careless in his reporting, provided that a similar text is reported through another isnäd as well (2) One with an isnäd containing a reporter who is known to be truthful and reliable, but is of lesser degree in his memory of hadith in comparison to the reporters of sabih hadiths. In both categories Ibn al-Salāh requires that the hadith be free of any shudhüdh (Ibn al-Salāh, 'Ulüm albadith, p. 27-28). A hadith da if is one of discontinuity in the isnäd, in which case the hadith could be mursal, mu'allaq, mudallas, munqati' or mu'dal. Maudū' (fabricated), is a hadith whose text goes against the established norms of Prophet's saying, or its reporters include a liar. It can also be recognized by external evidence related to a discrepancy found in the dates or times of a particular incident. The division of hadiths into sabịh, hasan and daif was first introduced by al-Tirmidhi (d. 279). This division was not known before him. See Ibn Taymiyya, 'Ilm al-ḥadith, Beirut 1985, p. 20. 
to obtain the compilation of a tradition together with the compiler's permission to transmit its content to others. The term to be used in this case was usually akbbarani. (5) Mukätaba. That is, to receive certain written traditions from a scholar, either in person or by correspondence, with or without his permission to narrate them to others. The term used in this kind of transmission was kataba ilayya or min kitäb. (6) I'läm al-rawni, that is, the declaration of a traditionist to a student that he received certain specified traditions or books from a specified authority, without giving the student permission to transmit the material. The terms used were akbbarani or 'an (7) Wasiya, i.e., to obtain the works of a traditionist by his will at the time of his death. The terms used were akbbarani wasiyyatan 'an or wașāni. (8) Wijäda, i.e., to find certain traditions in a book, perhaps after a traditionist's death, without receiving them with any recognized authority. The terms used were "wajadtu", "qāla", "ukbbirtu", "huddithtu" "77

Nevertheless, these terminologies and their meanings are historically problematic, because, as some investigations have pointed out, ${ }^{78}$ it seems that in early Islam there was no fixed terminology for the different forms of transmission. In other words, the terms were sometimes used interchangeably. ${ }^{79}$ This may reduce the specific meanings of the terms. This does not mean, however, that these terms do not have any historical value. These terms have to be evaluated critically in every scrutiny of a particular hadith. Furthermore, in imparting and receiving a particular badith, the transmitters might have used the terminology, which was usually used for $\operatorname{sam}^{-}$, although they did not receive the hadith in that way. This might have happened when

${ }^{77}$ For more detail see Al-Suyūtị, Tadrỉb al-rāwi, Cairo 1966, pp. 4-92; Fuat Sezgin, Geschichte des Arabischen Schrifttums, vol. 1, Leiden 1967, p. 58-60; Siddiqi, Hadith Literature, p. 86. James Robson, "Standarts Applied by Muslim Traditionists" in: The John Rylands Library 43, Manchester, 1960-61, pp. 470-474; Sabri al-Mutawalli, 'Ilm al-ḥadith al-nabawi, Cairo 2003, pp. 86-96.

${ }^{78}$ Kamaruddin Amin, "Nasiruddin al-Albani on Muslim Sahih. A Critical Study on his Methods". in Islamic Law and Society, vol. 11, Brill 2004, pp. 149-176; Motzki, Die Anfaenge, pp. 92-5.

79 See also Harald Motzki, Die Anf nge, p. 92-95; Kamaruddin Amin, “alAlbani...”, p. 159-161 
the transmitter was not reliable. ${ }^{80}$

On account of the occurrence in the canonical collections of unreliable hadith and in the light of the above-mentioned criteria, one may wonder whether the criteria of the collectors of kutub al-hadiths were exactly the same as the criteria by which those hadiths are assessed by later scholars. In other words, the above mentioned criteria were developed later than the time when the kutub al-hadiths were compiled. Moreover, a strict and consistent application of 'ulum al-hadith to hadith collections may uncover a large number of unreliable hadiths, which have hitherto been regarded by Muslim scholars as authentic. This fact may lead us to wonder whether the theoretical criteria reflect the earlier practice of hadith transmission and criticism.

${ }^{80}$ For example see, Syuhudi Ismail, Kaedah Kesahihan Sanad Hadis, p. 191-194 


\section{BIBLIOGRAPHY}

Abbott, Nabia, Studies in Arabic Literary Papyri II: Qur'anic Commentary and Tradition, (Chicago: The University of Chicago Press, 1976).

Amin, Kamaruddin, "Nasiruddin al-Albani on Muslim Sahih. A Critical Study on his Methods". in Islamic Law and Society, vol. 11 (Leiden: E.J. Brill 2004).

-, The Reliability of Hadith Transmission. A Reexamination of Hadith Critical Methods, Ph. D Dissertation (Bonn, 2005).

Al-'Aynī, Badr al-Din Abì Muhammad Maḥmūd Ibn Aḥmad, Umdat al-Qäri Sharh Saḅị̣ al-Bukhäri (Beirut, n.d.).

Azami, M. M., Studies in Early Hadith Literature: With a Critical Edition of Some Early Texts, 3rd ed. (Indianapolis, 1992).

Brown, Daniel W., Rethinking Tradition in Modern Islamic Thought, (Cambridge, 1996).

Caetani, L., Annali dell'Islam, vol. 1 (Milan, 1905).

Cook, Michael, "Eschatology and Dating of Traditions", in: Princeton Papers in Near Eastern Studies I (1992).

—, Early Muslim Dogma. A Source Critical Study (Cambridge, 1981).

-, and P. Crone, Hagarism. The Making of the Islamic World (Cambridge, 1977).

van Ess, Joseph, Zwischen Hadith und Theologie: Studien zum Entstehen pr destinatianischer berlieferung (Berlin/New York, 1975).

Gibb, H. A. R., Mohammedanism (Oxford, 1949).

Goldziher, Ignaz, Muhammedanische Studien, 2 vols. trans. S. M. Stern as Muslim Studies, 2 vols. (London, 1967).

Graham, William A., Divine Word and Prophetic Word in Early Islam: A Reconsideration of the Sources, with Special References to the Divine Saying or Hadith Qudsi (The Hague, 1977).

Hallaq, Wael B., "The Authenticity of Prophetic Hadith: a Pseudo Problem" in Studia Islamica 89, 1999.

Hasan, Ahmad, "The Sunna, its Early Concept and Development", in Islamic Studies, vol. 7, 1968. 
Humphreys, R. Stephen, Islamic History: A Framework for Inquiry, (Princeton, 1991).

Al-'Irāqi, 'Abd Rahịm b. Husayn, al-Taquid wa-Sharh Muqaddima Ibn alȘalăḥ (al-Maktaba al-Salafiyya, 1996).

Ismail, Syuhudi, Kaedah Kesahihan Sanad Hadis: Telaah Kritis dan Tinjauan dengan Pendekatan Ilmu Sejarah (Jakarta, 1988).

Juynboll, G. H. A., Muslim Tradition. Studies in Chronology, Provenance and Authorship of Early Hadith (Cambridge, 1983).

-, Studies on the Origins and Uses of Islamic Hadith (1996).

Kathir, Ibn, al-Bäith al-Hathith Sharh Ikbtisāar Ulüm al-Hadith (n.d.).

Motzki, Harald, "Quo vadis, Hadith Forschung? Eine kritische Untersuchung von G. H. A Juynboll: "Nafi', the Mawla of Ibn 'Umar, and his Position in Muslim Hadith Literature" in: Der Islam 73 (1996).

—, 'Der Fiqh des Zuhri: die Quellenproblematik' in Der Islam 68 (1991).

—, 'The Musannaf of 'Abd al-Razzāq al-San'āni as a Source of Authentic Abajatith of the First Century A.H: in Journal of Near Eastern Studies 50/1 (1991).

—, Die Anf nge der Islamischen Jurisprudence. Ihre Entwicklung in Mekka bis zur Mitte des 2./ 8 Jabrbunderts (Stuttgart, 1991).

-, The Biography of Muhammad: the Issue of the Sources (Brill, 2000).

Muir, William, The Life of Mahomet and the History of Islam to the Era of Hegira, 4 vols. (London, 1861); reprint. Osnabruck, 1988. First serialised in Calcutta Review 19 (January-June, 1853).

Al-Mutawalli, Sabri, 'Ilm al-Hadith al-Nabawi, (Cairo, 2003).

Al-Nawawi, Sahỉh Muslim bi-Sharḥ al-Nawawi, (Beirut, n.d.).

Al-Qastalāni, Irshād al-Säri li-Sharḥ Șaḩị̣ al-Bukhärì, (Bagdad, 1304).

Robson, James, "Standarts Applied by Muslim Traditionists" in The John Rylands Library 43, (Manchester, 1960-61).

Al-Ṣaddiq, Ibrāhìm b., Maqālāt wa-Muḅạdarāt fi'l-Hadith al-Sharif waUlūmih (Beirut: Dār al-Bashāir al-Islāmiyya, 2002/1423).

Schacht, Joseph, The Origins of Muhammadan Jurisprudence (Oxford, 1950). 
Al-Shāfi̊̄, Muḥammad b. Idrīis, Kitāb al-Risāla, ed. Aḥmad Muḥammad Shākir (Cairo, 1358/1940).

Shākir, Aḥmad Muhammad, Sharh Alfiyyat al-Suyūti fi Tlm al-Hadith (Beirut, n.d.).

Al-Shahrazūrî, 'Ulüm al-Hadith, ed. Nūr al-Din 'Itr, (Madinah, n.d.).

Al-Sibāīi, Muștafā, al-Sunna wa-Makānatuhā fìl-Tashrī al-Islāmi (Cairo, 1961).

Siddiqi, Muhammad Zubayr, Hadith Literature: Its Origin, Development and Special Features (Cambridge, 1993).

Sprenger, Alois, "On the Origin and Progress of Writing Down Historical facts among the Musulmans," Journal and Proceeding of the Asiatic Society of Bengal 25 (1856).

-, "Die Sunna" in Alois Sprenger, Das Leben und die Lehre des Mohammad, lxxvii-civ. (Berlin, 1861-1865).

Al-Suyūtị, Jalāl al-Dīn, Tadrỉb al-Rāwi fi Sharḥ Taqrỉb al-Nawawi, ed 'Abd al-Wahhāb 'Abd al-Lațif (Madinah, 1972/1392).

Al-Ṭahhān, Maḥmūd, Taysir Mustalạ̣ al-Hadith (Beirut, 1399/1979).

Al-'Umarì, Muhammad Qāsim, Dirāsat fi Manbaj al-Naqd 'inda'lMuhadditbin (Yordan, 2000).

Wansbrough, J., The Sectarian Milieu, Content and Composition of Islamic Salvation History (Oxford, 1978).

Zahw, Muhammad Muhammad Abū, al-Hadith wa'-Muhaddithūn (Cairo, 1957/1378).

Zaman, Iftikhar, "The science of Rijal as a method in the Study of Hadith", Journal of Islamic Studies 5:1 (1994). 